\title{
Design of Asymmetric Peptide Bilayer Membranes
}

\author{
Sha Li', Anil K. Mehta ${ }^{2 *}$, Anton N Sidorov³, Thomas M. Orlando ${ }^{3,4}$, \\ Zhigang Jiang ${ }^{4}$, Neil R. Anthony5, David G Lynn ${ }^{1 *}$ \\ ${ }^{1}$ Departments of Biology and Chemistry, ${ }^{2}$ Emory NMR Center, ${ }^{3}$ School of Chemistry and Biochemistry and ${ }^{4}$ School of Physics, \\ Georgia Institute of Technology, ${ }^{5}$ Emory Integrated Cellular Imaging Core, ${ }^{1,2,5}$ Emory University, Atlanta GA 30322
}

\section{Methods}

Circular Dichroism. Samples ( $30 \mu \mathrm{L}$ ) were placed into a quartz cuvette with a $0.1 \mathrm{~mm}$ path length (Starna Cells, Atascadero, CA, USA) and analyzed using a JASCO J-81o spectropolarimeter fitted with a Peltier temperature controller Each spectrum was obtained from $300 \mathrm{~nm}$ to $180 \mathrm{~nm}$ at a scan rate of $100 \mathrm{~nm} / \mathrm{min}$ with a resolution of $0.2 \mathrm{~nm}$. Three successive wavelength scans were averaged for each sample. The elipticity $\left([\theta]_{\text {obs }}, \mathrm{mdeg}\right)$ is converted to mean residue ellipticity $\left([\theta], \mathrm{deg} \cdot \mathrm{cm}^{2} \cdot \mathrm{dmol}^{-1}\right)$ with the equation $[\theta]=[\theta]_{\mathrm{obs}} /(10 \times \mathrm{n} \times \mathrm{C} \times \mathrm{l})$, in which, $\mathrm{n}$ is the number of peptide bonds, $C$ is the concentration $(\mathrm{mol} / \mathrm{L})$ and $\mathrm{l}$ is the path length of the cell $(\mathrm{cm})$. Buffer control spectra were averaged and subtracted from the sample spectra. For melting experiments, an aliquot (50-70 $\mu \mathrm{L}$ ) of a peptide assembly is placed in $0.1 \mathrm{~mm}$ path length demountable window cell (Starna Cells) with Teflon tape wrapped around the window edges to minimize evaporation. Elipticity at $225 \mathrm{~nm}$ was recorded over a 15 minute period at $4^{\circ} \mathrm{C}$ until stabilized. The elipticity at $225 \mathrm{~nm}$ was recorded as a function of temperature in increments of $2{ }^{\circ} \mathrm{C} / \mathrm{min}$ and fit to the sigmoidal form of the Boltzmann equation.

Fourier-Transform Infrared Spectroscopy. Sample aliquots $(10 \mu \mathrm{L})$ were dried as thin films on an ATR diamond cell and the spectra acquired using a Jasco FT-IR 4100 ATR at room temperature. Typically 256 scans were acquired with $4 \mathrm{~cm}^{-1}$ resolution. Background spectra were acquired immediately before each sample and subtracted from each sample spectrum.

$\mathrm{X}$-ray powder diffraction. Mature peptide nanotube assemblies were bundled with either sulfate or magnesium at a peptide to salt ratio of 1:10, and the resulting white precipitate collected by centrifugation. The pellet was frozen and lyophilized to yield dry powder for X-ray diffraction. Powder spectra were obtained using a Bruker D8 Discover diffractometer equipped with a multiposition X, Y, Z stage, a cobalt X-ray tube with Goebel mirror and a Vantecı solid-state detector. The sample was placed in a zerobackground holder on the stage and the spectrum obtained using Bragg-Brentano geometry. The scan step was repeated several times to maximize the diffracted intensity and minimize noise.

Confocal Imaging. Mature assemblies $(\mathrm{mMM})$ are diluted 10 times and loaded onto a $22 \times 50 \mathrm{~mm} \# 1.5$ coverslip in a custom designed holder and enclosed with a $22 \times 30 \mathrm{~mm}$ coverslip. Fluorescence images are taken on an Olympus Fluoview 1000 Confocal Microscope using an Olympus 6oX oil immersion (PlanApo N, 1.42 NA) objective lens. Each fluorescence intensity acquisition consisted of one frame at $1024 \times 1024$ pixels with dimensions $212 \times 212 \mu \mathrm{m}, 106 \times 106 \mu \mathrm{m}$ or $70 \times 70 \mu \mathrm{m}$ and the images were acquired approximately $2-5 \mu \mathrm{m}$ below the glass surface. The image data are analyzed using Olympus Fluoview and FIJI. 


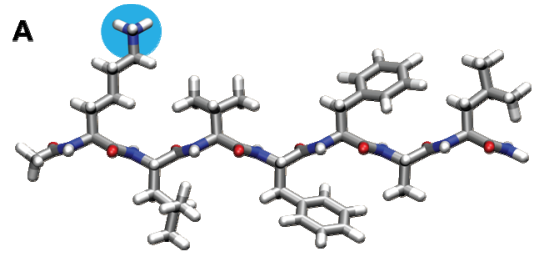

D

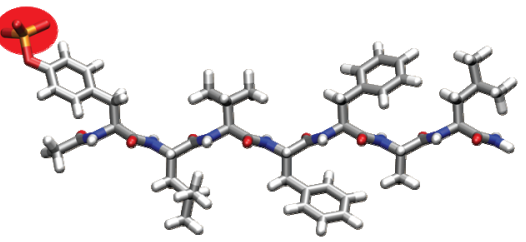

B
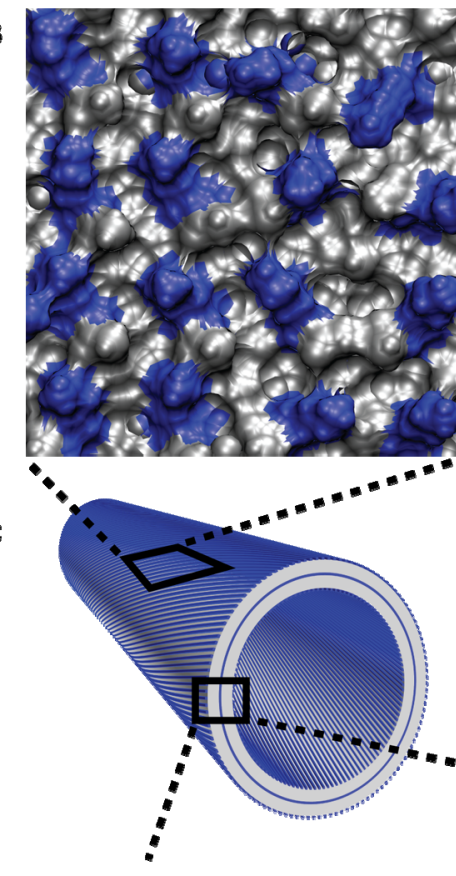

E

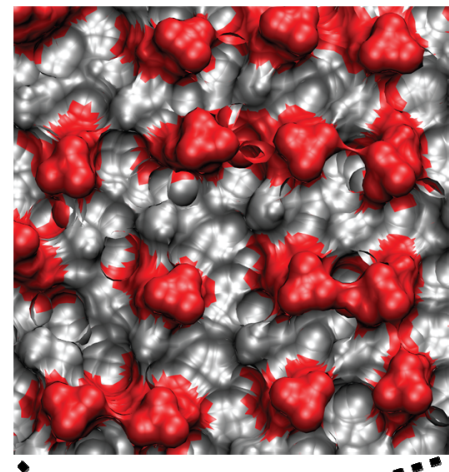

$\mathbf{F}$

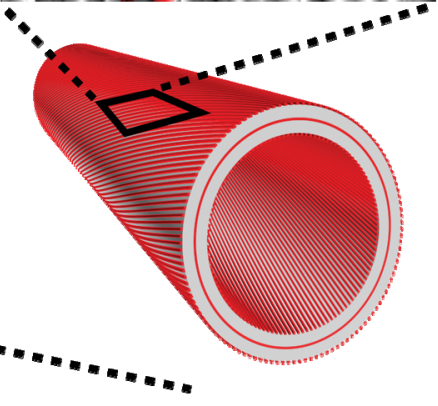

$\because$

G



$90^{\circ} \frac{\lambda}{2}$

H

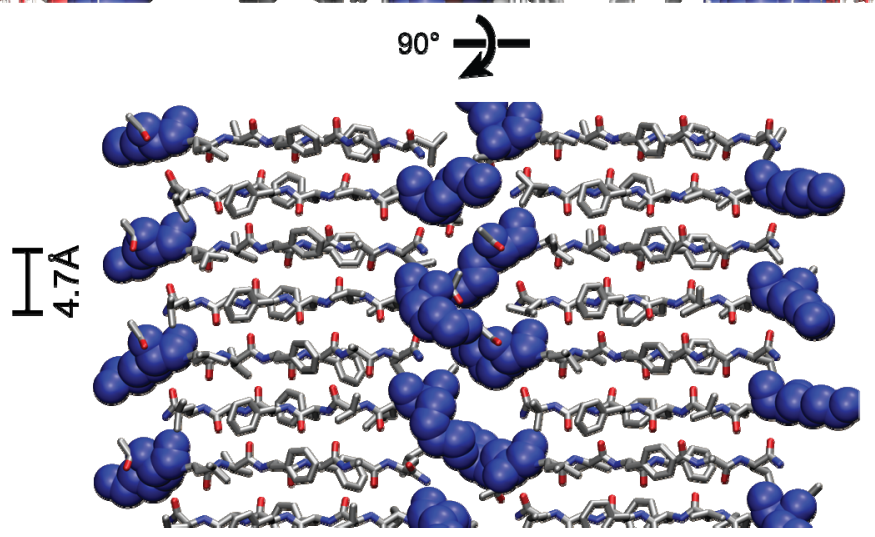

Figure S1. Models of (A-C) Ac-KLVFFAL- $\mathrm{NH}_{2}(\mathrm{~K})$ and (D-F) Ac-(pY)LVFFAL- $\mathrm{NH}_{2}(\mathrm{pY})$ nanotubes. Solvent exposed surface of (B) K peptide nanotubes with hydrophobic surface colored grey and lysine residues colored blue and (E) pY peptide nanotubes with $\mathrm{pY}$ residues colored red. (G) K-peptide bilayer with positive charge of lysine sidechains passivated by acetate counter-ions at peptide leaflet interface showing water (thin lines), peptide (thick lines), lysine residues (space filled blue) and acetate counter-ions (space filled with oxygen colored red, carbon grey and hydrogen white). (H) Top view of peptide $\beta$-sheet showing arrays of lysine resides (space filled colored blue) at the peptide $\beta$-sheet leaflet interface. 

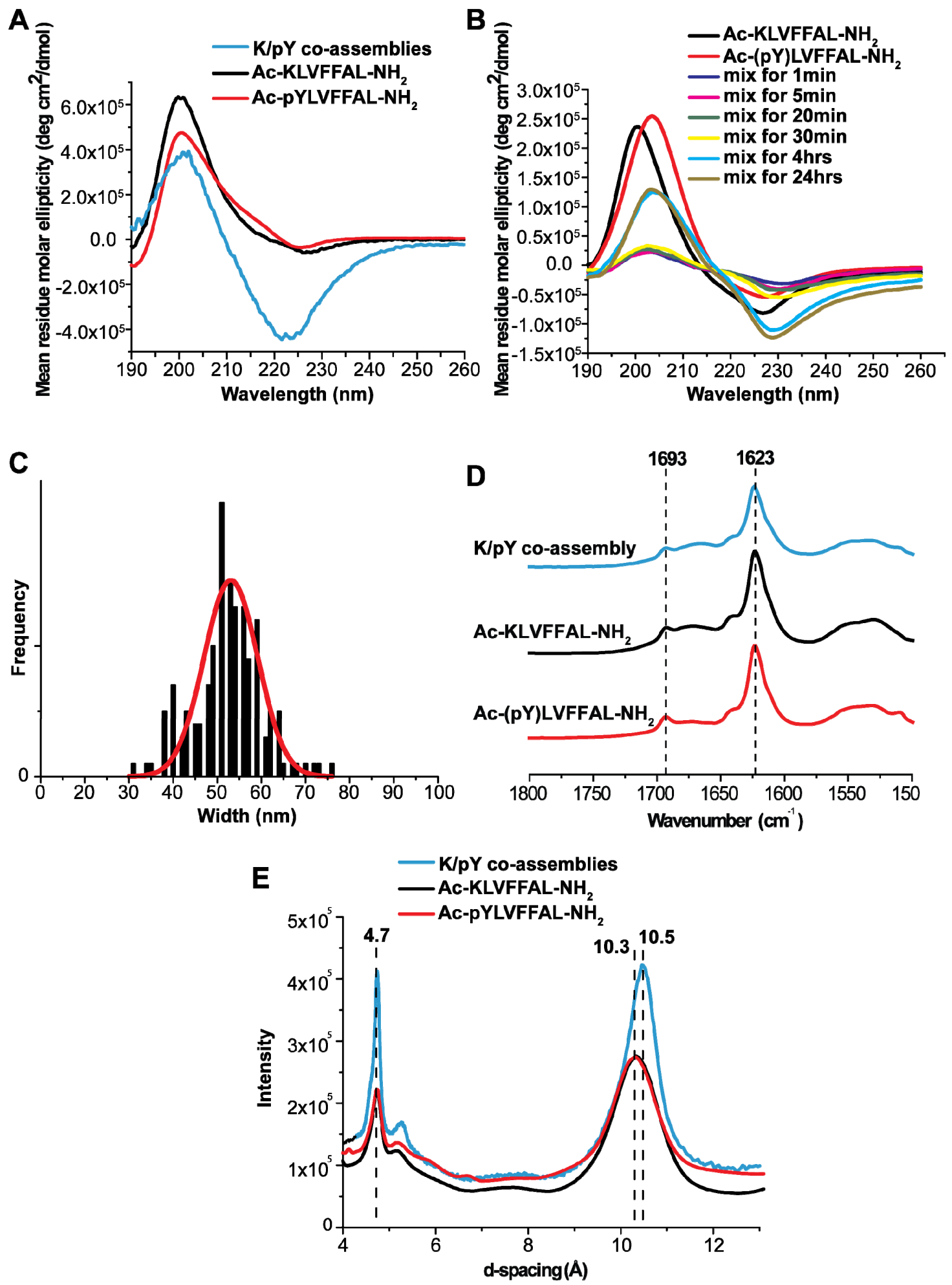

Figure S2. (A) Circular Dichroism spectra of $1 \mathrm{mM} \mathrm{K}$ peptide nanotubes (black) assembled in $40 \% \mathrm{MeCN} / \mathrm{H}_{2} \mathrm{O}$ with TFA, $1 \mathrm{mM} \mathrm{pY}$ nanotubes (red) in $40 \% \mathrm{MeCN} / \mathrm{H}_{2} \mathrm{O}$ with TEAA and $\mathrm{K} / \mathrm{pY}$ peptide nanotubes (blue) pelleted and resuspended as a 1:1 molar ratio in $40 \% \mathrm{MeCN} / \mathrm{H}_{2} \mathrm{O}$ and (B) followed over the indicated time series. (B) CD spectra taken at 7 weeks of mature $\mathrm{K}$ nanotubes (black), $\mathrm{pY}$ nanotubes (red) and $\mathrm{K} / \mathrm{pY}$ co-assembled nanotubes (blue) in $40 \% \mathrm{MeCN} / \mathrm{H}_{2} \mathrm{O}$ displaying minima at $225 \mathrm{~nm}$ and maxima at 202 $\mathrm{nm}$, consistent with $\beta$-sheet secondary structure; (C) K/pY peptide co-assembly width measurements from TEM micrographs. Histograms are fit to a Gaussian with center of $53.1 \pm 1.2 \mathrm{~nm}$ and width of $14.4 \pm 2.7 \mathrm{~nm}$. Nanotube diameters can be estimated as diameter $=$ width $^{*} 2 / \pi$ to give $34 \pm 0.8 \mathrm{~nm}$. (D) FT-IR spectra of $\mathrm{K}$ nanotubes, $\mathrm{pY}$ nanotubes and $\mathrm{K} / \mathrm{pY}$ co-assemblies in $40 \%$ $\mathrm{MeCN} / \mathrm{H}_{2} \mathrm{O}$ after 6 week incubation, show a strong IR stretch at $1623 \mathrm{~cm}-1$, consistent with an amide-I $\beta$-strand stretch and a weaker band at $1693 \mathrm{~cm}-1$, consistent with anti-parallel $\beta$-strand orientation.; (E) X-ray powder diffraction of mature K/pY peptide co-assemblies (blue), K peptide nanotubes (black) and pY peptide nanotubes (red), showing reflections at d-spacings of $4.7 \AA$ defining the spacing between $\mathrm{H}$-bonded $\beta$-strands and at 10.5 $\AA$ for peptides in adjacent $\beta$-sheets. 

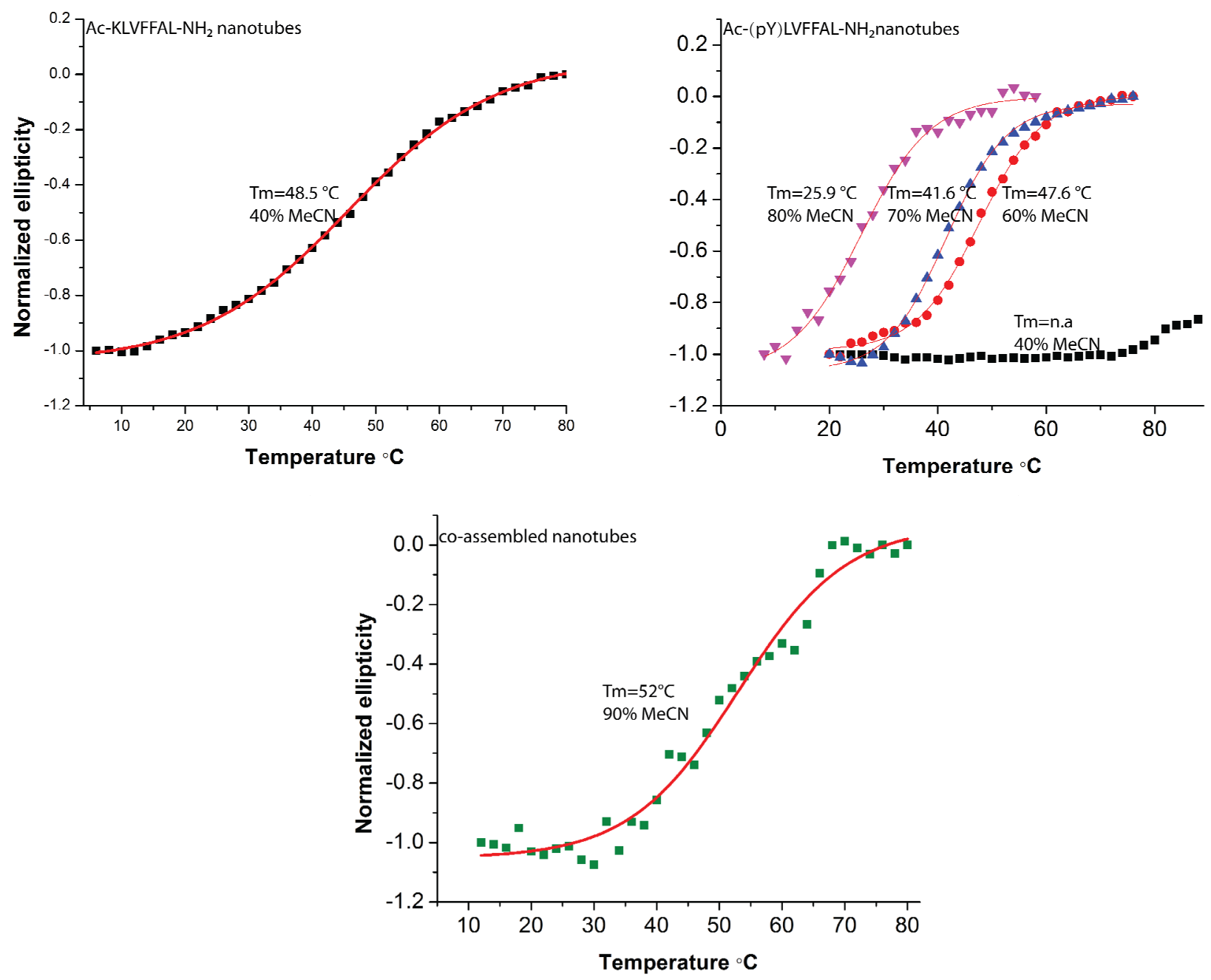

Figure S3. Thermal melting of the peptide assemblies. Melting temperatures ( $\mathrm{Tm}$ ) are evaluated in $\mathrm{MeCN} / \mathrm{H}_{2} \mathrm{O}$ by circular dichroism (CD) peak intensity at $225 \mathrm{~nm}$ expressed as a function of temperature. Each assembly displays a cooperative melting transition fit to the sigmoidal form of the Boltzmann equation:

$$
\theta \propto\left(1+\exp \left\{\frac{T_{m}-T}{k}\right\}\right)^{-1},
$$

where melting cooperativity is reflected in the slope, $\mathrm{k}$. Under the assembly conditions $\left(40 \% \mathrm{MeCN} / \mathrm{H}_{2} \mathrm{O}\right)$, only AcKLVFFAL-NH2 (K) nanotubes melt (top left) as indicated by the loss of negative ellipticity, before significant evaporation of acetonitrile complicated measurements $\left(80^{\circ} \mathrm{C}\right)$. The melting curve was fit to $\mathrm{y}=-0.4729+(-34.3734+0.4729) /(1+\exp ((\mathrm{T}-48.4598) / 15.5563))$, corresponding to a melting point of $48.5 \pm 15.6^{\circ} \mathrm{C}$. (Top Right) Ac-(pY)LVFFAL-NH2 (pY) nanotubes remained stable in $40 \%$ $\mathrm{MeCN} / \mathrm{H}_{2} \mathrm{O}$, but when pelleted and re-suspended with different amounts of $\mathrm{MeCN}$ co-solvents, cooperative melting curves were observed. In $60 \% \mathrm{MeCN}$, the melting fits to $\mathrm{y}=0.0036+(-0.9853-0.0036) /(1+\exp ((\mathrm{T}-47.6493) / 5.8079))$, to give a $\mathrm{Tm}$ of $47.6 \pm 5.8^{\circ} \mathrm{C}$. In $70 \% \mathrm{MeCN} / \mathrm{H}_{2} \mathrm{O}$, the $\mathrm{Tm}$ fit to $\mathrm{y}=-0.0284+(-1.0651+0.0284) /(1+\exp ((\mathrm{T}-41.6053) / 5.5344))$, is $41.6 \pm 5.5^{\circ} \mathrm{C}$., and in $80 \% \mathrm{MeCN}, \mathrm{y}=-$ $0.0012+(-1.0698+0.0012) /\left(1+\exp \left((\mathrm{T}-25.8740) / 6.3733\right.\right.$, is $25.9 \pm 6.4^{\circ} \mathrm{C}$ (Bottom) Co-assembled nanotubes re-suspended in $90 \%$ $\mathrm{MeCN} / \mathrm{H}_{2} \mathrm{O}, \mathrm{y}=0.6409+(-23.4538-0.6409) /(1+\exp ((\mathrm{T}-51.9535) / 10.2994))$, melted at $52 \pm 10.3^{\circ} \mathrm{C}$. 
Table S1. Melting temperature of Ac-KLVFFAL-NH ${ }_{2}$, Ac-(pY)LVFFAL-NH ${ }_{2}$ and co-assemblies.

\begin{tabular}{|c|c|c|}
\hline Sample & Melting condition & Tm $\left({ }^{\circ} \mathrm{C}\right)$ \\
\hline Ac-KLVFFAL-NH & & $48.5 \pm 15.6$ \\
\hline Ac-(pY)LVFFAL-NH & $40 \% \mathrm{MeCN} / \mathrm{H}_{2} \mathrm{O}$ & $\begin{array}{c}\text { no observed } \\
\text { transition }\end{array}$ \\
\hline Ac-(pY)LVFFAL- $\mathrm{NH}_{2}$ & $40 \% \mathrm{MeCN} / \mathrm{H}_{2} \mathrm{O}$ & $47.6 \pm 5.8$ \\
\hline Ac-(pY)LVFFAL-NH & $60 \% \mathrm{MeCN} / \mathrm{H}_{2} \mathrm{O}$ & $41.6 \pm 5.5$ \\
\hline Ac-(pY)LVFFAL-NH & $70 \% \mathrm{MeCN} / \mathrm{H}_{2} \mathrm{O}$ & $25.9 \pm 6.4$ \\
\hline $\begin{array}{c}\text { Ac-KLVFFAL-NH } \\
\text { (pY)LVFFAL-NH } \mathrm{N}_{2} \text { co- } \\
\text { assemblies }\end{array}$ & $80 \% \mathrm{MeCN} / \mathrm{H}_{2} \mathrm{O}$ & $52 \pm 10.3$ \\
\hline \begin{tabular}{c} 
Ac- \\
\hline
\end{tabular} & $90 \% \mathrm{MeCN} / \mathrm{H}_{2} \mathrm{O}$ & \\
\hline
\end{tabular}



Figure $\mathrm{S}_{4}$. Linear extrapolation of Ac-(pY)LVFFAL- $\mathrm{NH}_{2}$ nanotube melting temperature as a function of $\mathrm{CH}_{3} \mathrm{CN}$ concentration. 

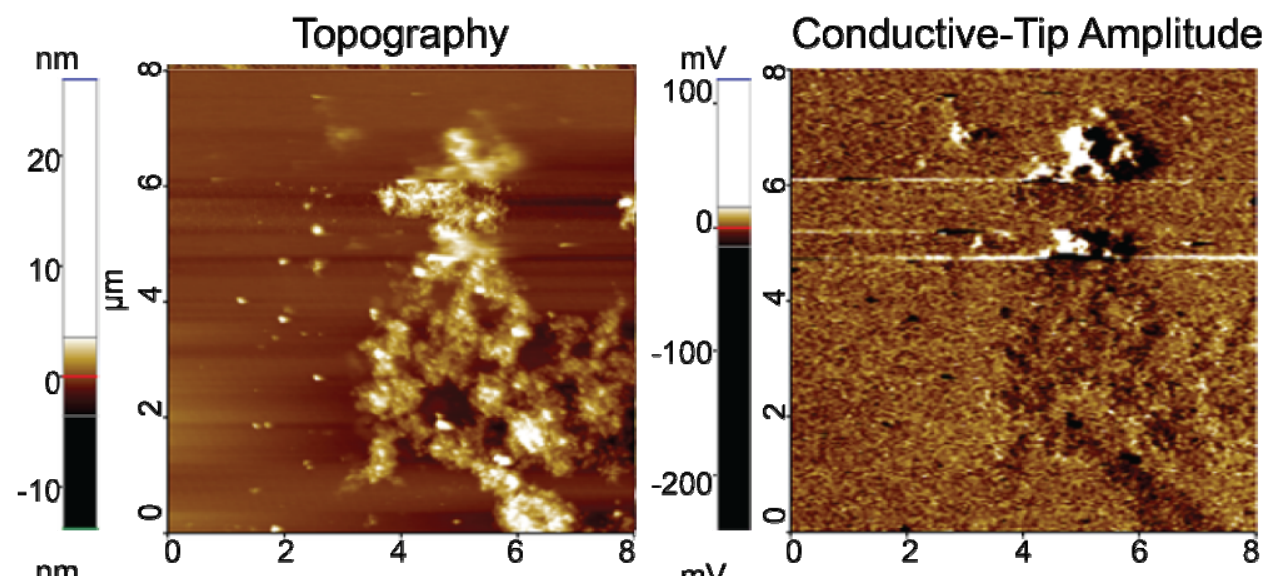

Time


3days

20days

7 weeks

Figure S5. EFM analyses of K/pY during co-assembly. Topography (left) and EFM (right) micrographs of co-assembly of the two peptides proceeds in $40 \% \mathrm{MeCN} / \mathrm{H}_{2} \mathrm{O}$ at neutral $\mathrm{pH}$. The DC probe bias $+1 \mathrm{~V}$ and here the positively charged surfaces appear as light and the negatively charged surfaces dark in the amplitude micrographs. 




Figure S6 Atomic (AFM) and electrostatic force micrographs (EFM) of (A) K and (B) pY nanotube assemblies. Topography (left) and EFM amplitude (right) micrographs of peptide nanotubes using a DC bias of +1 V. In the EFM amplitude micrographs the positively charged surfaces are light and negatively charged surfaces are dark. (reproduced from ref. 13- main text) 


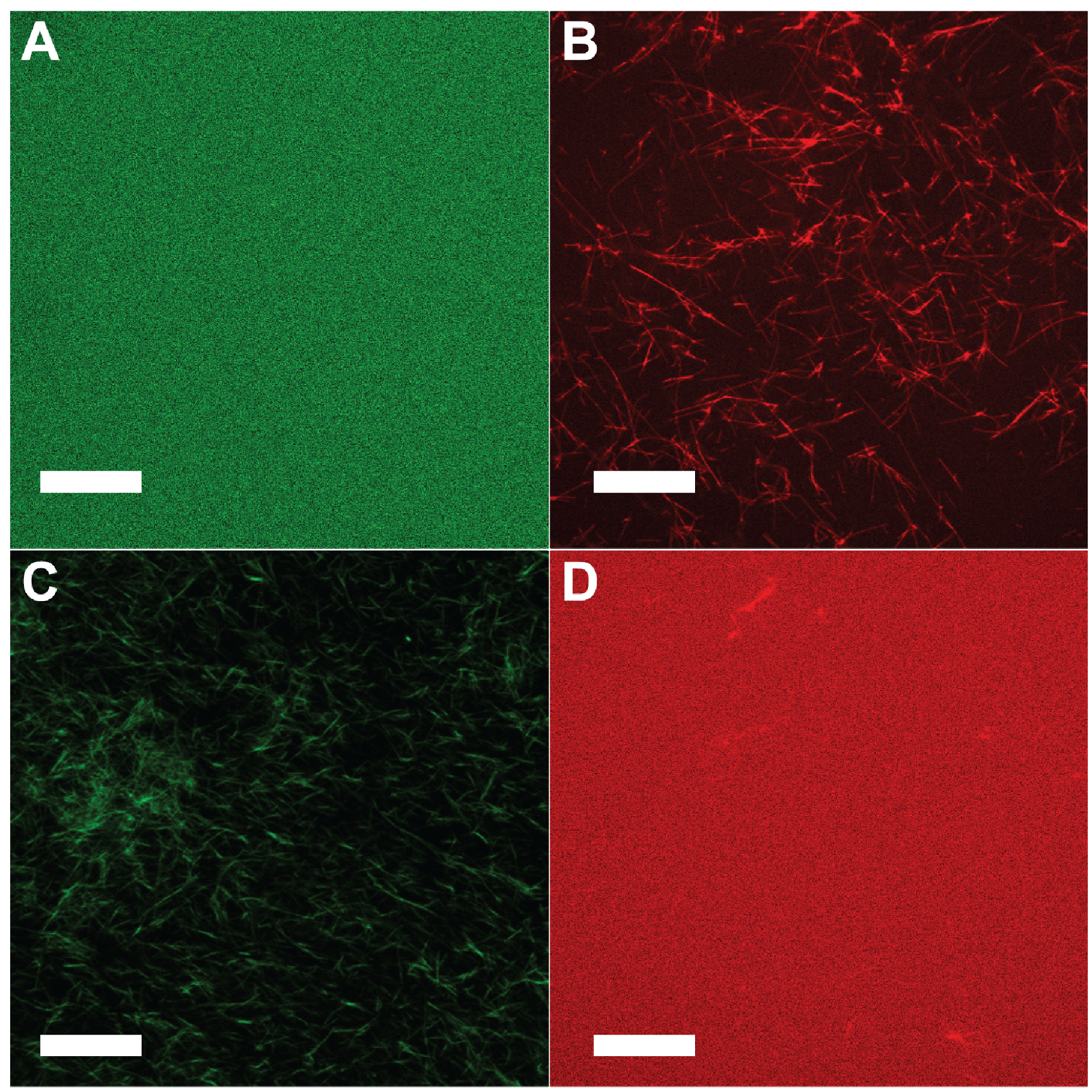

Figure S7. Confocal images of dye binding to $\mathrm{K}$ and $\mathbf{p Y}$ nanotubes. Single confocal fluorescence images of (A) acridine orange in the presence of $\mathrm{K}$ nanotubes, (B) Alexa 633 in the presence of $\mathrm{K}$ nanotubes, (C) acridine orange in the presence of pY nanotubes, and (D) Alexa 633 in the presence of pY nanotubes. Scale bar $40 \mu \mathrm{m}$. 


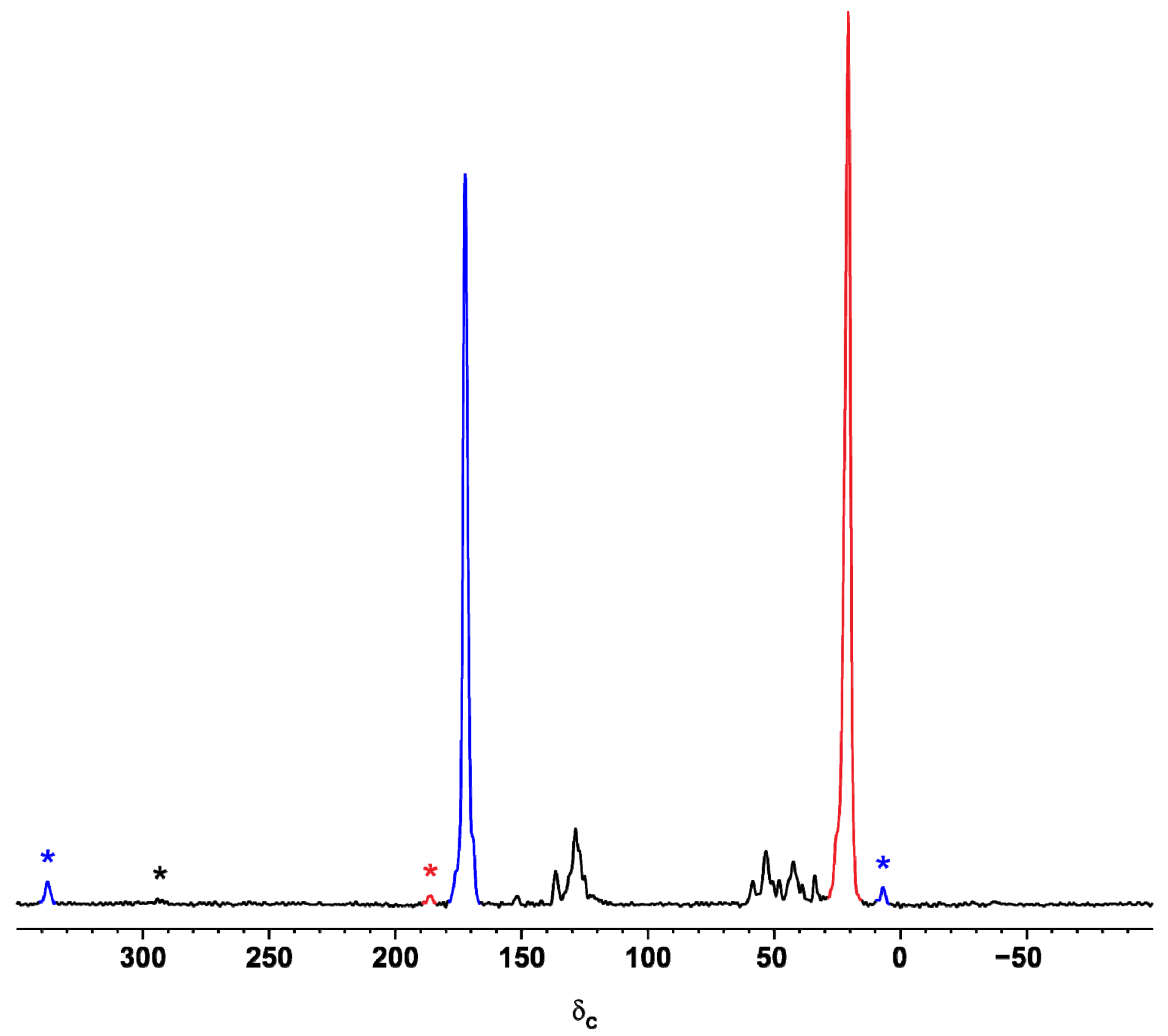

Figure S8. ${ }^{13} \mathrm{C}(75.475 \mathrm{MHz}) \mathrm{CP}-\mathrm{MAS}$ NMR spectra of $\left[1^{-13} \mathrm{C}\right] \mathrm{A}$ (Ac-KLVFFAL) and $\left[3^{\left.-{ }^{13} \mathrm{C}\right] \mathrm{A}}\right.$ (Ac-pYLVFFAL). Asterisks indicate spinning sidebands. Prior to assembly, a 1:1 pY:K peptide ratio was confirmed by HPLC. Integration of $\mathrm{NMR}$ [1- $\left.{ }^{13} \mathrm{C}\right] \mathrm{Ala}$ and $\left[3^{\left.-{ }^{13} \mathrm{C}\right] \mathrm{Ala}}\right.$ transition intensities gives a pY: $\mathrm{K}$ peptide ratio of 1:0.74. Both the ${ }^{13} \mathrm{C}$ enriched residue and the natural abundance residues contribute the observed carbonyl and methyl intensities. Assuming that the ${ }^{13} \mathrm{C}$ enriched peptide has 99 units of magnetization and natural abundance ${ }^{13} \mathrm{C}^{\prime}$ s give rise to 1.1 units of magnetization, the total ${ }^{13} \mathrm{C}$ intensities can be calculated from the concentration of $\mathrm{pY}\left(\mathrm{C}_{\mathrm{pY}}\right)$ and $\mathrm{K}\left(\mathrm{C}_{\mathrm{K}}\right)$ containing peptides as: $\left({ }^{13} \mathrm{CH}_{3}\right)_{\text {intensity }}=99 \mathrm{C}_{\mathrm{pY}}+{ }_{1.1} \mathrm{C}_{\mathrm{K}}$, assuming that the natural abundance contribution from the K-peptide is negligible, this simplifies to: $\left({ }^{13} \mathrm{CH}_{3}\right)_{\text {intensity }}=99 \mathrm{C}_{\mathrm{pY}}$. Similarly $\left({ }^{13} \mathrm{CO}\right)_{\text {intensity }}=99 \mathrm{C}_{\mathrm{K}}+\left(1.1^{*} 6^{*} \mathrm{C}_{\mathrm{K}}\right)+\left(1.1^{*} 7^{*} \mathrm{C}_{\mathrm{pY}}\right)$. Substituting $\left({ }^{13} \mathrm{CH}_{3}\right)_{\text {intensity }}=1$ and $\left({ }^{13} \mathrm{CO}\right)_{\text {intensity }}=0.736$, gives: $\mathrm{C}_{\mathrm{pY}}=1 / 99=0.01$. And $\mathrm{C}_{\mathrm{K}}=\left(0.736-7 \cdot 7^{*} 0.01\right) /(99+6.6)=0.00624$. The result can be normalized to a peptide concentration ratio of $C_{\mathrm{pY}}=1$ and $\mathrm{C}_{\mathrm{K}}=0.62$. 

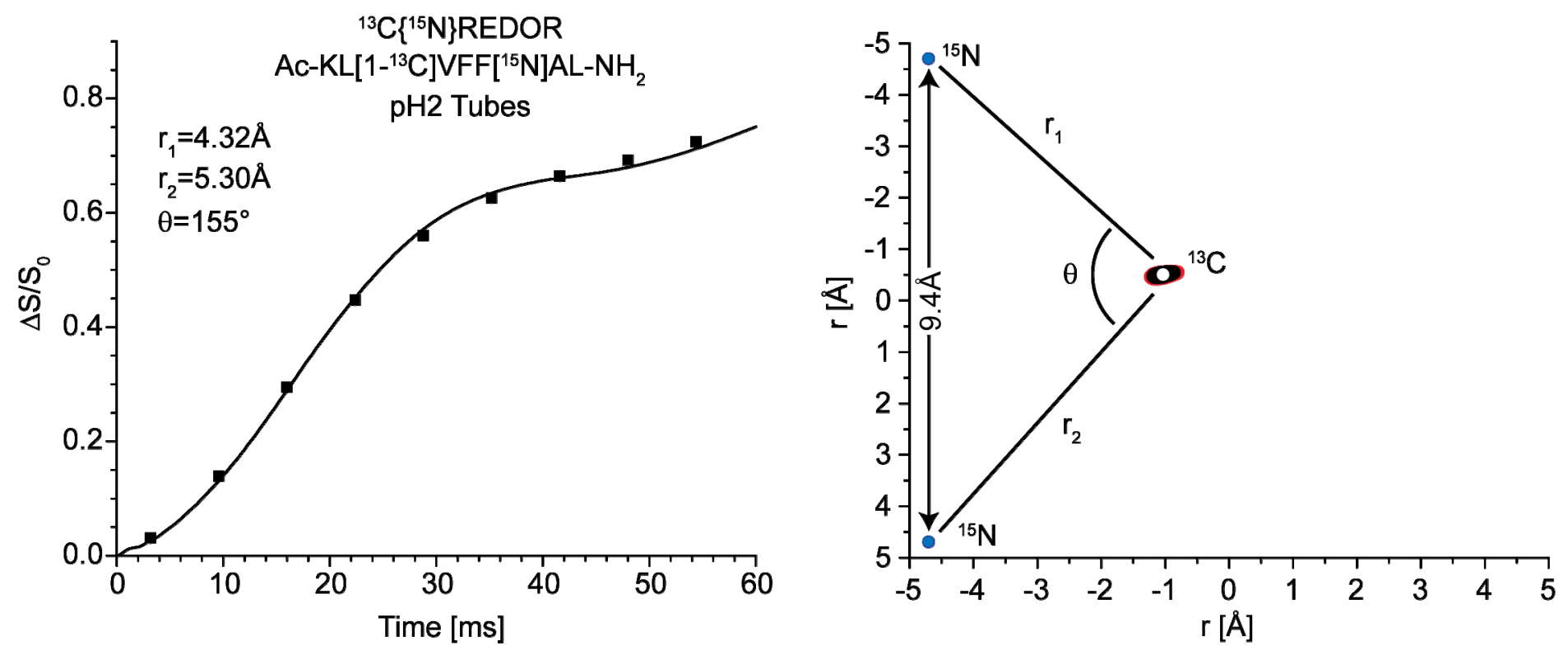

Figure S9. ${ }^{13} \mathrm{C}\left\{{ }^{15} \mathrm{~N}\right\} R E D O R$ dephasing of $\mathrm{Ac}-\mathrm{KL}\left[1^{-13} \mathrm{C}\right] \mathrm{VFF}\left[{ }^{15} \mathrm{~N}\right] \mathrm{AL}-\mathrm{NH} 2$ peptide nanotubes. (Left) Solid line is best fit to experimental data from grid search with ${ }^{13} \mathrm{C}$ coupled to two ${ }^{15} \mathrm{~N}$ with distances of $\mathrm{r}_{1}=4 \cdot 32 \AA, \mathrm{r}_{2}=5 \cdot 30 \AA$ and an $\mathrm{N}-\mathrm{C}-\mathrm{N}$ angle of $155^{\circ}$. Error bars are the size of the data points. (Right) ${ }^{13} \mathrm{C}$ positions that fit data within experimental error. Best position is indicated with white circle and blue circles represent ${ }^{15} \mathrm{~N}$ positions. The ${ }^{13} \mathrm{C}\left\{{ }^{15} \mathrm{~N}\right\}$ REDOR simulated curves ${ }^{1}$ include contributions ${ }^{2}$ from natural abundance ${ }^{13} \mathrm{C}$ at $1.325 \AA$ and $2.4 \AA$ corresponding to $\mathrm{Phe}{ }^{13} \mathrm{CO}$ that is directly bonded to [ $\left.{ }^{15} \mathrm{~N}\right] \mathrm{Ala}$ and from Ala ${ }^{13} \mathrm{CO}$ respectively. 

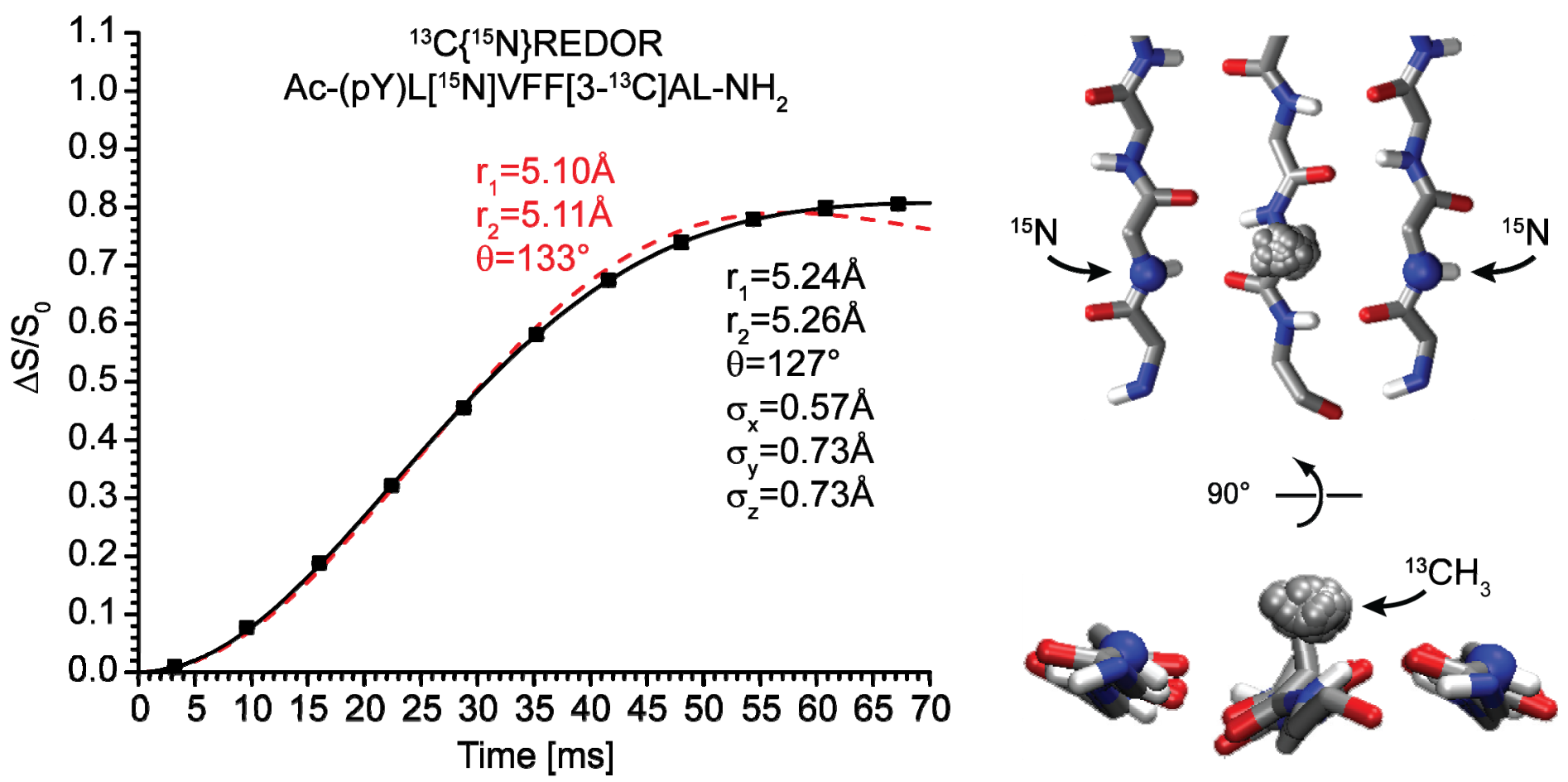

Figure S1o. ${ }^{13} \mathrm{C}\left\{{ }^{15} \mathrm{~N}\right\} R E D O R$ dephasing of $\mathrm{Ac}-(\mathrm{pY}) \mathrm{L}\left[{ }^{15} \mathrm{~N}\right] \mathrm{VFF}\left[3^{-13} \mathrm{C}\right] \mathrm{AL}-\mathrm{NH} 2$ peptide nanotubes. (Left) Dashed line is best fit for ${ }^{15} \mathrm{~N}-$ ${ }^{13} \mathrm{C}-{ }^{15} \mathrm{~N}$ three spin system with ${ }^{13} \mathrm{C}-{ }^{-15} \mathrm{~N}$ distances of $\mathrm{r}_{1}=5.1 \AA$ and $\mathrm{r}_{2}=5.11 \AA$ and ${ }^{15} \mathrm{~N}-{ }^{13} \mathrm{C}-{ }^{15} \mathrm{~N}$ angle of $133^{\circ}$ and solid line is simulated ${ }^{13} \mathrm{C}-{ }^{15} \mathrm{~N}$ REDOR curve assuming a $3 \mathrm{D}$ distribution approximating Ala methyl positions from MD simulations with ${ }^{13} \mathrm{C}$ positions described by a $3 \mathrm{D}$ Gaussian with widths of $0.57 \AA$ parallel to the $\mathrm{C} \alpha-\mathrm{CH}_{3}$ bond and $0.73 \AA$ along the length of the peptide and parallel to the $\mathrm{H}$ bonds. (Right) Representative snapshots of $3.6 \mathrm{~ns}$ MD simulation of Ac-(pY)LVFFAL- $\mathrm{NH}_{2} \beta$-sheet highlighting distribution of Ala methyl positions.

\section{References}

(1) Goetz, J. M.; Schaefer, J. J Magn Reson 1997, 127, 147.

(2) Bernard, G. M.; Miskolzie, M.; Kotovych, G.; Wasylishen, R. E. Can J Chem 2004, 82, 1554. 